DOI 10.18551/rjoas.2021-12.13

\title{
THE INFLUENCE OF HALAL LABELS, BRAND IMAGE AND PRODUCT QUALITY ON THE DECISION TO PURCHASE POP MIE CUP INSTANT NOODLE PRODUCTS
}

\author{
Laksana Dwi Hari ${ }^{\star}$, Yudhiantoro Danang \\ Faculty of Economics and Business, UPN "Veteran" Yogyakarta, Indonesia \\ *E-mail: dhlaksana@upnyk.ac.id
}

\begin{abstract}
The purpose of this study was to find out how the influence of halal labels, brand image and product quality on the decision to buy pop noodle cup instant noodle products in Bantul district, Yogyakarta. The population in this study is all consumers of Pop Mie Cup in Kasihan Bantul Subdistrict. Purposive sampling technique is selective selection. The data collection method is to distribute questionnaires to 115 consumers who have purchased pop mie at least once. Data analysis techniques use multiple linear regression models with the help of the SPSS program version 20.0. This research resulted in 1) Halal labels, brand image and product quality influence simultaneously on the decision to purchase Pop Mie Cup products, 2) Halal labels influence the decision to buy Pop Mie Cup products, 3) Brand image influences the decision to buy Pop Mie Cup products, 4) Product quality influences the decision to buy Pop Mie Cup products, 5) Price influences the decision to buy Pop Mie Cup products.
\end{abstract}

\section{KEY WORDS}

Halal label, brand image, product quality, purchase decision.

In today's era along with the rapid advancement of technology, new companies are emerging that create products or services to meet all consumer needs and demands. Increasing consumer needs and demands can be measured by the increasing welfare of the community. The large consumer demand is the cause of the emergence of new companies in the same field, causing so much competition in the business world itself. Indonesia, which has a Muslim population of $90 \%$ of the total number of its citizens, will have a dilemma to choose the desired products, especially food products. The public will be facilitated with a wide selection of products, but will also be confused with the problem of the page of the product itself. With this halal label consumers will be facilitated to choose which products are allowed to be consumed. In addition to halal labels, brand image factors, product quality and price are also considered by consumers in making purchasing decisions.

Pop Noodles is an instant noodle in the form of a cup of Indomie, launch for the first time with chicken flavor and meatball flavor, produced by PT. Indofood Sukses Makmur is a company engaged in the business of the food processing industry whose almost all its products dominate the market in Indonesia. Indofood is the largest producer of instant noodles in Indonesia and Southeast Asia. Products produced include instant noodles (Indomie, Sarimi, Supermie, Mie Gelas, Pop Mie, Intermie, Sakura). Pop Mie is a noodle that has the slogan "Puasin Laper Lo, Puasin Muda Lo" targeting young people who suddenly hungry in an urgent situation, which is expected to be able to this is driving sales of the Pop Mie Cup to increase every year.

Companies create and offer their products in the market, the manufacturer will definitely find out first and learn about what is needed by consumers. Plus there is such a thing as instant noodles in cup packaging that can be brought at picnics or on the go. In addition, people today prioritize halal, filling and also practical food in instant cup noodle food, so that producers can adjust according to consumer needs. From these conditions the higher level of education and public awareness of health. Then consumers are easier in choosing products that are really healthy and halal in consuming instant cup noodle products. 
With time, brands of Instant Noodles in Cup packaging sprung up. There are several brands of Instant Noodles in cup packaging that are currently competitors of the Pop Mie Cup, namely Mie Sedaap Cup, and Mie ABC Cup. As for the phenomenon that occurs in Pop Mie Cup Brand Food products where the product decreases its sales every year.

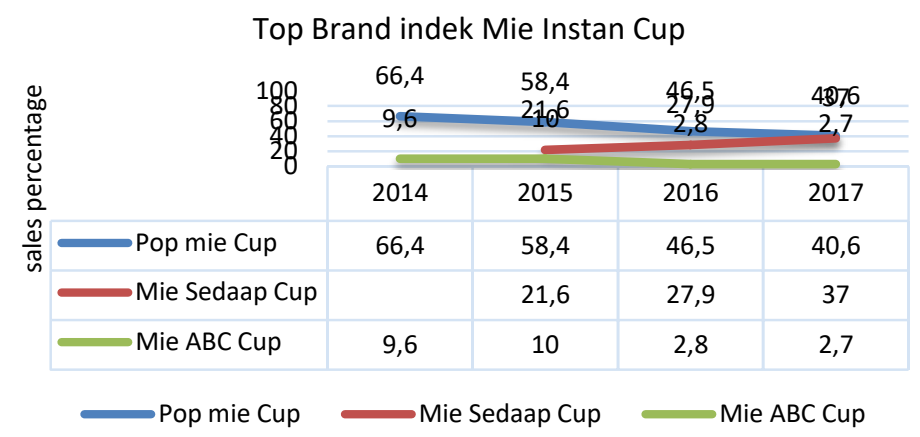

Figure 1 - Comparison of Cup Noodle Sales in 2014-2017

(Source: award.com http://www.topbrand, 2017)

Based on the data, Pop Mie Cup instant noodle products decreased the percentage of sales in the top brand index, in 2014 to 2015 experienced a decrease of $8 \%$, then in 2015 it experienced a decrease of $8 \%$, then in 2015,2015 to 2016 by $11.9 \%$ and in 2016 to 2017 decreased by $5.9 \%$. While Mie Enak cup which is a competitor experienced a percentage increase in sales by $6.3 \%$ in 2016, and also in 2017 by $9.1 \%$. And for ABC cup noodle competitors also experienced an increase and decrease in sales presentations in 2014 and 2015 increased by $0.4 \%$ and decreased in 2015 to 2015 . 2016 was $7.2 \%$ and in the following year 2016 to 2017 by $0.1 \%$.

Although Pop Mie Cup as the market leader, but the percentage of sales in 4 consecutive years experienced a continuous decline in other areas as well as the Mie Sedap Cup which annually increased while Mie ABC Cup sales presentation experienced ups and downs, if not evaluated the cause of the decrease in sales of Pop Mie Cup products will be rivaled by competitors Mie Enak Cup and Mie ABC Cup. This shows that it is important for manufacturers to improve the strategies used so that their purchasing decision levels are maintained properly and able to maintain their dominance. in the competition of Instant Cup Noodle products, especially Muslim consumers. The inclusion of halal labels is basically not mandatory, but if the product is included in the territory of Indonesia which is majority Muslim then it is mandatory to include halal labels and be responsible for idolatry. the product so that the consumer's right to correct, clear and honest information about the condition and guarantee of goods and services is protected properly and adequately. The existence of this rule marketers must consider the aspects of the page of a product, so that the Muslim community can give confidence to the product and this problem. Must be completed immediately so that consumers are willing to make purchasing decisions.

According to the Ministry of Religious Affairs contained in Kepmenag RI No.518 of 2001 concerning the examination and determination of halal food does not contain illegal elements or materials or is prohibited for consumption by the ummah. Islam and its management is not contrary to Islamic law. With this halal label consumers will be more facilitated to choose which products are allowed to be consumed. A label can be part of the packaging or the etiquette (identification) listed on the product. If labels can help Pop Mie Cup consumers to determine whether or not a foodies halal, then halal labels are very important to distinguish between halal and not food. Especially for Muslim consumers. If the Halal Label is accepted by Muslim consumers as expected, it can be the reason a consumer makes a decision to buy Pop Mie Cup products.

In addition to halal labels, the problem of consumers in choosing products is the brand image itself. Brand image is also one of the consumer factors for determining the purchasing decision of a product. Where a brand image is a set of perceptions and beliefs that 
customers have about a brand reflected through associations that exist in the customer's memory (Kotler and Keller, 2012: 263). Imagery cannot be instilled in the minds of consumers overnight or disseminated through a single medium. Instead, the image must be conveyed through every means of communication that is available and disseminated continuously because without a strong image it is very difficult for a company to Attract new customers and retain existing customers. If the customer feels a good image it will lead to positive consumer behavior, such as the desire to repurchase the same brand, increase purchases and I want to recommend the brand to others. Brand image also plays an important role because it concerns the reputation and credibility of the brand itself in the minds of consumers, so as to improve purchasing decisions on products. Pop Noodle Cup.

One of the advantages in this competition is mainly the quality of products that can meet the desires of consumers. According to Mowen (2012: 61) Product bag cauldron is an overall evaluation process to customers for improvements in the performance of a product. The company must provide the best in terms of product quality, so that consumers will be interested in buying the product.

In addition to halal labels, brand image, and product quality price factors are also considered by consumers in making purchasing decisions. According to Basu Swastha (2010: 147) means that the price is a sum of money (plus some items if possible) needed to add a number of combinations of goods and the service. According to Daryanto (2013: 62) defines price as the amount of money charged for a product or the amount of value that consumers exchange for the benefit of owning or using the product. Decisions regarding prices become very important especially to maintain and improve the company's position in the market. In addition to increasing a company's sales and profits, proper pricing can affect consumers. Companies can set the prices offered close to the prices of competitors in order to attract the attention of consumers. Consumers will then compare the prices offered by the Pop Mie Cup whether more expensive or cheaper when compared to its competitors, namely the Mie Sedap Cup and ABC Cup before making a decision. to consume one of these products.

According to Suharno (2010: 167) a purchasing decision is the stage at which the buyer has determined and made the purchase of the product, as well as consuming it. According to Fandy Tjiptono (2014: 21) purchasing decisions are a process by which consumers recognize the problem, seek information about a particular product or brand and evaluate how well each of these alternatives can solve the problem, which then leads to a purchasing decision.

\section{THEORETICAL REVIEW}

Halal comes from the Arabic word meaning to let go or not to be bound. Etymologically halal means things that can be done freely or not bound by things that prohibit it. While according to the Association of Indonesian Ulema Councils (MUI) is food that is allowed to eat it according to Islamic teachings (Ministry of Religious Affairs, 2003). Halal labelization is the establishment of halal writing or statement on product packaging to show that the product in question is a halal product, in Indonesia authorized institutions. By the government in the halal certification process is the Indonesian Ulema Council (MUI).

According to Government Regulation No. 69 article 10 of 2010, everyone who produces or enters food, drugs and cosmetics packaged into the territory of Indonesia for trade, and declare that the food is halal for Muslims, is responsible for the truth of the statement and is obliged to include halal information or writing on the label.

There are several types of labels including:

- Brand label, i.e. brand given on the product or listed on the packaging;

- Descriptive label, which provides objective information about the use, construction / manufacture, attention / maintenance and performance of the product, and other characteristics related to the product;

- Grade label, which is a label that identifies a product quality assessment with a letter, number or word. For example, fruits in cans are labeled as quality A, B, and C. 
There are several functions of labels as follows:

- Identify a product or brand;

- Determine the class of the product;

- Describe the product, who made it, where it was made, what it contained, how to use it safely;

- Promote products through interesting graphics.

The understanding of Halal according to the Ministry of Religious Affairs contained in the decree of the Minister of Religious Affairs of the Republic of Indonesia number 518 of 2001 concerning the torture of Halal Food is "doesn't contain elements or illegal ingredients or is prohibited for consumption by Muslims and its processing is not contrary to Islamic sharia." It is said that halal must at least meet three criteria, namely the substance, how to obtain it, and halal how to process it. Meanwhile, halal products are products that meet the requirements of idolatry in accordance with Islamic sharia (Burhanuddin, 2011: 140) namely:

- It does not contain pork and ingredients derived from pigs;

- It does not contain prohibited substances such as materials derived from human organs, blood, dirt and so on;

- All materials derived from halal animals slaughtered according to Islamic sharia ordinances;

- All storage, place of sale, processing, processing and transportation should not be used for pigs. If ever used for pigs or other unfancy goods must first be cleaned in a manner regulated according to Islamic sharia;

- All food and drink that does not invite khamar.

There is a significant relationship that halal labels influence purchasing decisions. The inclusion of halal label products is done to provide protection to Muslim consume, due to the many problems of halal labialization on products that contain ingredients that are haram to be consumed to anticipate this then in the production process the need for provisions of the terms of the terms of the page of a product. The existence of halal labels listed on product packaging, it will directly have an influence for consumers, especially the Muslim community to use the product. The emergence of a sense of security and comfort in consuming the product will increase the trust and interest in buying in purchasing decisions.

Brand image is a series of associations (perceptions)that exist in the minds of consumers towards a brand, usually organized into a meaning. The relationship with a brand will be stronger if it is based on experience and a lot of information. Images or associations present perceptions that reflect objective reality or not. Brand image describes the extrinsic nature of a UK product or service the way in which a brand seeks to meet the psychological or social needs of customers. According to Tjiptono (2015:49) brand image is a description of consumer association and confidence in a particular brand. According to Kotler and Keller (2012: 263) define brand image as a set of perceptions and beliefs that customers have in a brand that is reflected through existing associations. in the customer's memory. When a brand image has been able to build product character and provide a value proposition, then convey the character of the product to its customers uniquely, This means that the image has given an emotional power more than the rational power possessed by the product. This makes customers associate positive things in their thinking when they think of the image. formation:

Schiffman and Kanuk (2010: 135) mention the following factors of brand image

- Quality or quality is related to the quality of goods or services offered by manufacturers with a particular brand;

- Trustworthy or reliable, relating to opinions or agreements formed by the public about a product consumed;

- Usefulness or benefit, related to the function of a product of goods or services that can be utilized by consumers;

- Service, which relates to the duty of the manufacturer in service;

- Risk, related to the magnitude of the consequences or profit and loss that may be experienced by consumers; 
- Price, which in this case relates to the high low or the least amount of money that consumers spend to influence a product, can also affect the long-term image;

- The image owned by the brand itself, i.e. in the form of views, agreements, and information related to a brand of a particular product. namely:

Tjiptono and Diana (2012: 17) state that brand image has a variety of purposes,

- As a corporate identity that distinguishes it from competitors' products so that it is easily recognized;

- As a promotional tool that accentuates the attractiveness of the product (for example with design shapes and interesting colors);

- To foster an image, namely by providing confidence, quality assurance, as well as a certain prestige image to consumers;

- To control and dominate the market. This means that by building a brand that is wellknown, good-imaged, and protected exclusive rights based on copyright/ patent, the company can achieve and maintain consumer loyalty.

According to Kotler and Keller (2012:347), brand image can be seen from:

- The advantage of brand association, one of the factors forming brand image is the superiority of the product where the product excels in competition;

- The power of brand association, every valuable brand has a soul, a special personality is a fundamental obligation for the brand owner to be able to express, socialize the soul / personality in one form of advertising, or other forms of promotional and marketing activities. That is what will continue to be a link between the product / brand and the customer. Thus the brand will be quickly recognized and will be maintained in the midst of rampant competition. Building the popularity of a brand into a well-known brand is not easy. Nevertheless, popularity is one of the keys that can shape the brand image in customers;

- The uniqueness of the brand association is the purity of the product.

According to Freddy Rangkuti (2011:44) The Brand Image Indicator is as follows:

- Recognition. The level of recognition of a brand by consumers, if a brand is not known then the product with that brand must be sold by relying on the cheapest price such as logo recognition, tagline, design products and other things as the identity of the brand;

- Reputation (Reputation). It is a high level of reputation or status for a brand because it has a better track record, a brand favored by consumers will be easier to sell and a product. Those who are perceived to have high quality will have a good reputation. Such as the perception of the consumer and the quality of the product;

- Affinity (Attraction). An emotional relationship that arises between a brand and its consumers can be seen from the price of consumer satisfaction and the level of association;

- Loyality. It concerns how much consumer loyalty of a product that uses the brand in question.

According to Kotler and Keller (2012: 263) define brand image as a set of perceptions and beliefs that customers have about a brand that is reflected through associations that exist in the customer's memory. In order to create a good brand image in the mind of consumers, the company must improve the quality of the product. The better the image of a brand, the higher the decision to make a purchase.

One of the main values expected by customers from manufacturers is the highest quality of products and services. Product quality is how describing the product can provide something that can satisfy consumers. According to Fandy Tjiptono (2012: 121) suggests that quality is as a direct picture of a product such as performance, reliability, easy use, aesthetics and so on. According to Alma (2013: 139) Products are a set of attributes both tangible and intangible including issues of color, price, good name of the factory, good name of the store selling (retailer), and factory service, and retailer services received by buyers to satisfy desire. 
According to Mowen (2012: 61) Product Quality is an overall evaluation process to customers for improvements in the performance of a product. According to Assauri (2015: 211) product quality is a statement of the level of ability of a particular brand or product in carrying out its expected functions. According to Kotler and Armstrong (2012:230) defines that: product quality: "is one of the marketer's major positioning tols." Which means the product cauldron is one of the main positions in a marketing. According to Vincent Garpersz (2011:04) that definition of quality produ: "Quality is everything that is able to meet the wishes or needs of consumers." Which means quality is everything that is able to meet the wants or needs of consumers.

According to Kotler and Keller translated by Bob Sabran (2012:143) product quality is the ability of a product to deliver appropriate results or performance even beyond what the customer wants. Meanwhile, according to Wijaya (2011: 11) Product quality is the overall combined characteristics of products resulting from marketing, engineering, production and maintenance that make the product available to meet customer or consumer expectations.

There are several opinions about the dimensions of product quality, among others according to Kotler and Keller translated by Bob Sabran (2012: 8) if the company wants to maintain its competitive advantage in the market then the company must understand what aspects of dimensions are used by consumers to distinguish the products sold by the company with competitors' products. Therefore, the quality of the product can be entered into nine dimensions, namely:

- Form (Form). Products can be clearly distinguished from others based on the shape, size, or physical structure of the product;

- Product features (Feature). Secondary or complementary characteristics that are useful for adding basic functions related to product choices and their development;

- Performance (Performance). It deals with the functional aspects of an item and is the main characteristic that customers consider in buying the item;

- Accuracy/conformity (Conformance). Relating to the level of conformity with the specifications set in advance based on customer's wishes. Conformity reflects the degree of accuracy between product design characteristics and standard quality characteristics that have been set;

- Durability (Durability). Relating to some time a product can be used without causing problems with use;

- Reliability (Reliability). With regard to the probability or probability of an item successfully carrying out its function every time it is used in a certain period of time and under certain conditions as well;

- Ease of repair (Repairability). Related to convenience, repair or product if damaged. Ideally the product will be easily repaired by the user if damaged;

- Style (style). Product performance and consumer impression of the product;

- Design (Design). The overall specialty of the product that will affect the appearance and function of the product to the consumer's wishes.

Price is one of the important components that must be considered by the company. The price must be determined precisely in order to increase the expected sales. Price can also be a measure to know how much a good or service is worth and is one of the factors that determine the success or absence of a good or service in the market. In determining the price, the company must pay attention to the level of market price by looking at the competition that occurs and the target market to be entered.

According to Kotler and Keller (2012: 345) describes price as the value that consumers exchange for the benefit of owning and using a product or service that allows the company to earn a reasonable profit by paying for the customer value it creates. According to Daryanto (2013: 62) defines price as the amount of money charged for a product or the amount of value that consumers exchange for the benefit of owning or using the product. While Basu Swastha (2010: 147) explained that the price is the amount of money (plus some items if possible) needed to get a combination of goods and servants. Mahmud Machfoed (2010:281) price is the amount of money charged on services. The price is the amount of 
value exchanged by consumers to obtain the benefits of ownership or use of a product or service. According to Fandy Tjiptono (2015: 291) there is a price role that is as follows:

- The price chosen directly affects the level of demand and determines the level of activity. Prices that are too expensive or vice versa are too potential to hinder product development. Therefore, the measurement of price sensitivity is very important to do;

- The selling price directly determines the profitability of the operation;

- Prices set by a company affect the general perception of a product or brand and contribute to brand positioning;

- Price is a direct tool or vehicle to make comparisons between competing products or brands. In other words, the price is the "Forced point of contact between competitions";

- Pricing strategies should be aligned with other components of the marketing mix. Prices should be able to cover development, promotion and distribution costs;

- The acceleration of technological developments and the shorter the product life cycle demand accurate pricing from the start;

- The proliferation of brands and products that are often without adequate differentiation has implications for the importance of proper price positioning;

- Government regulations, ethics, and social considerations (such as price control, setting maximum profit margins, authorization of pricing, and so on) limit a company's autonomy and flexibility in pricing;

- Reduced purchasing power in some regions of the world has an impact on higher price sensitivity which in turn strengthens the role of price as a driving instrument of sales and market share.

Price assessment can be seen from the conformity between a sacrifice that consumers make to the value they receive after making a purchase. A positive assessment is the result of a sense of satisfaction or a product he buys while a negative assessment is a form of consumer dissatisfaction with the product he buys.

According to Kotler and Armstrong translation of Bob Sabran (2012:278) price indicators are as follows:

- Price-up. Consumers can reach the price set by the company. Products usually have several types in one brand and the price also differs from cheapest to most expensive. With the price set by many consumers who buy the product;

- Prices according to ability or price competitiveness. Consumers often compare the price of one product with other products. In this case the high price of a product is highly considered by consumers at the time of buying the product;

- Price compatibility with product quality. Prices are often used as an indicator of quality for consumers' people often choose a higher price between two goods because they see a difference in quality. If the price is higher people tend to assume that the quality is also better;

- Price suitability with benefits. Consumers decide to buy a product if the perceived benefit is greater than the one that has been issued to get. If the consumer feels the benefits of the product are less than the money spent then the consumer will assume that the product is expensive and the consumer will think twice about repurchase.

A decision involves a choice between two or more alternative actions (behaviors). Each consumer makes a wide range of decisions about the search, purchase, use of a variety of products and brands at any given period. Purchasing decisions are the process by which buyers choose one of several choices based on the product or brand to consume. According to Fandy Tjiptono (2014: 21) purchasing decisions are a process by which consumers recognize the problem, seek information about a particular product or brand and evaluate how well each of these alternatives can solve the problem, which then leads to a purchasing decision. According to Kotler and Keller (2012:166), "Buying decision is process all the experiences in learning, choosing using, and event disposing of a product". Which means that purchasing decisions are all experiences in learning, selecting, using, and even getting rid of products. According to Buchari Alma (2013: 96) stated that the purchase decision is a 
consumer decision influenced by financial, technological, political, cultural, product, price, location, promotion, physical evidence, people and, process. Thus forming an attitude on consumers to process all information and draw conclusions in the form of responses that appear what products will be purchased. According to Peter and Olson (2013: 163) purchasing decisions are an integrity process that combines knowledge to evaluate two or more alternatives and choose one of them.

According to Sangadji and Sopiah (2013: 24) there are 3 main factors to make a purchase decision:

- Psychological Factors. These factors include perception, motivation, learning, attitude, and personality. Attitudes and beliefs are psychological factors that make consumer purchasing decisions;

- Situational factors. Situational factors include the state of the advice and infrastructure of the place of shopping, shopping time, use of products, and conditions at the time of purchase;

- Social factors. Social factors include laws/regulations, families, reference groups, social and cultural classes.

According to Kotler and Keller (2012: 166) there is a stage in making a purchase decision, namely:

- Problem recognition. The process begins when the buyer is aware of a problem or need triggered by internal and external stimuli. Internal stimulation appears to ourselves such as when we are feeling thirsty and hungry, then the stimulus will rise into a drive or need that usually arises due to external stimuli such as seeing food or drink;

- Information seeker. In conducting the search for brand-related information that consumers want obtained from various sources such as family, friends, advertising, packaging, and display. But in general consumers get the most important information of a brand from commercial, namely sources that circulate widely in the community such as advertising and websites. In addition, in conducting a search for consumer information also conducts searches for other brand products;

- Alternative evaluation. Some basic concepts that will help in understanding the evaluation process. First, the consumer is trying to meet their needs. Second, consumers are looking for certain benefits from product solutions. Third, consumers see each product as a group of attributes with varying capabilities to deliver the benefits necessary to satisfy a need. Consumers will pay the greatest attention to the attributes that have the most benefit in meeting their needs;

- Purchasing decision. In this stage the consumer has made a purchasing decision and has felt the benefits directly from the desired product;

- Post-purchase behavior. After a purchase, consumers may experience conflicts due to seeing flaws in their products or hearing pleasant things about other brands' products.

According to Kotler (2012:166) indicators of purchasing decisions are: purpose in buying a product; processing information to get to brand selection; stability in a product; give recommendations to others; make a repurchase.

That there is a significant relationship of halal labels influences purchasing decisions. The inclusion of halal label products is done to provide protection to Muslim people, due to the many problems halal labeling on products that contain ingredients that are haram to be consumed to anticipate this then in the production process the provision of the terms of the terms of a product. The existence of halal labels listed on product packaging, it will directly have an influence for consumers, especially the Muslim community to use the product. The emergence of a sense of security and comfort in consuming the product will increase the trust and interest in buying in purchasing decisions. Consumers are increasingly critical to choose a product, thus halal label assurance information is very influential on consumer purchasing decisions. According to Zani's research, Deoranto and Effendi (2013) mentioned that halal labels have a significant influence on purchasing decisions. Therefore, halal labels 
affect the level of purchasing decisions. Based on this explanation, the first hypothesis of this study is as follows:

H1: Halal label influences the decision to purchase Pop Mie Cup products in Kasihan Bantul Subdistrict.

Consumers, who have a positive image of a brand, will be more likely to make purchases. A better brand is also the basis for building a positive corporate image. According to Kotler and Keller (2012: 263) define brand image as a set of perceptions and beliefs that customers have about a brand that is reflected through associations that exist in the customer's memory. In order to create a good brand image in the mind of consumers, the company must improve the quality of the product. The better the image of a brand, the higher the consumer's decision to make a purchase.

Based on the discussion above, it can be said that brand image is also one of the determining factors of purchasing decisions. This is evidenced by research from Muhammad Taufik Saputro (2018) mentioning that brand image has a positive and significant influence on purchasing decisions. Based on this explanation, the second hypothesis of this study is:

H2: Brand image influences the decision to buy Pop Mie Cup products in Kasihan Bantul Subdistrict.

Product quality is also one of the determining factors of purchasing decisions. Consumers will pay close attention before deciding to buy a product, if the product is of good quality. Because a quality product will cause an attraction for consumers to buy the product. According to Kotler and Armstrong (2012:230) defines that: product quality: "is one of the marketer's major positioning." Which means the product cauldron is one of the main positions in a marketing. Good product quality will provide its own added value in the minds of consumers. Consumers will be very satisfied if the product they use is of good quality.

Based on the discussion above, it can be said that the product is also one of the determining factors of purchasing decisions. This is evidenced by research from Muhammad Taufik Saputro (2018) mentioned that the quality of products has a significant effect on purchasing decisions. Therefore, the quality of the product affects the level of purchasing decisions.

H3: Product quality affects the decision to buy Pop Mie Cup products in Kasihan Bantul Subdistrict.

Price is a factor in consumer considerations in choosing and making purchasing decisions of a product or service. According to Kotler and Keller (2012: 345) describes price as the value that consumers exchange for the benefit of owning and using a product or service that allows the company to earn a reasonable profit by paying for the customer value it creates. Information about prices is important for consumers to know. The price of a product can reflect the quality of the product in question. Before making a purchase decision, consumers usually compare prices elsewhere first. Consumers tend to choose stores that offer cheaper prices compared to rival prices. According to research by Pramudi Artanto and Hendri Sukotjo (2016) mentioned that price has a significant effect on purchasing decisions. Therefore, the price

H4: Price affects the decision to buy Pop Mie Cup products in Kasihan Bantul District.

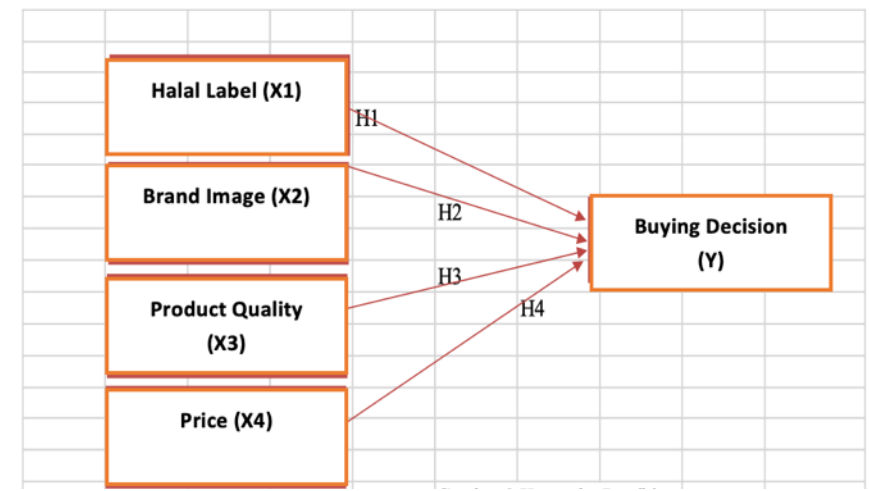

Figure 2 - Research Framework (Source: Yusuf Andriansyah Journal, Rois Arifin, and Afi Rachmat S.) 


\section{METHODS OF RESEARCH}

This research is included in the type of research with the survey method, with the aim to find out the influence of Halal Label, Brand Image, Product Quality and Price on Pop Noodle Cup Product Purchase Decisions. This observation was made on consumers of Pop Mie Cup in Kasihan Bantul Subdistrict. The population in this study was all Pop Mie cup consumers in Kasihan Bantul district with a sample of 115. Sampling technique with Purposive Sampling method is consumers who have bought and consumed pop cup noodles at least once or even more.

The type of data used in this study is using primary data, namely researchers directly provide questionnaires to respondents related to variables that are examined by researchers.

The type of variable in the study is the Independent Variable with " $X$ " symbol which includes Halal Label (X1), Brand Image (X2), Product Bag Cauldron (X3) and Price (X4). And Variable Bound (Dependent Variable) with symbol "Y" that is the Decision of Theian ( $Y$ ).

Before analyzing the data first, test validity and reliability. Validity test results show that all question items can be declared valid, and reliability results find all variables can be declared reliable. The data analysis technique in this study used multiple regression analysis with the help of the SPSS program version 20.0.

The validity test in this study used item analysis that correlates the score of each item. If there are items that do not qualify, then the item will not be further investigated. The requirement that must be met is that the question item is said to be valid if the value $r$ calculates the $>r$ of the table or the value $p<0.05$. The results of the question item validity test on the questionnaire using 30den responses can be seen in Table 1.

\begin{tabular}{|c|c|c|c|c|c|c|}
\hline Variable & Item & $\mathrm{r} 2$ & r Table & $p$ Value & Alpha & Description \\
\hline \multirow{4}{*}{ Halal Label (X1) } & $\mathrm{X} 1.1$ & 0,994 & 0,361 & 0.000 & 0.005 & Valid \\
\hline & $\mathrm{X} 1.2$ & 0,929 & 0,361 & 0.000 & 0.005 & Valid \\
\hline & $\mathrm{x} 1.3$ & 0,994 & 0,361 & 0.000 & 0.005 & Valid \\
\hline & $\mathrm{X} 1.4$ & 0,994 & 0,361 & 0.000 & 0.005 & Valid \\
\hline \multirow{4}{*}{ Brand Image (X2) } & $\mathrm{X2.1}$ & 0,55 & 0,361 & 0.000 & 0.005 & Valid \\
\hline & $\mathrm{X2.2}$ & 0,951 & 0,361 & 0.000 & 0.005 & Valid \\
\hline & $\mathrm{X2.3}$ & 0,951 & 0,361 & 0.000 & 0.005 & Valid \\
\hline & $\times 2.4$ & 0,912 & 0,361 & 0.000 & 0.005 & Valid \\
\hline \multirow{5}{*}{ Product Quality (X3) } & \begin{tabular}{|l|l}
3.1 \\
\end{tabular} & 0,971 & 0,361 & 0.000 & 0.005 & Valid \\
\hline & $\times 3.2$ & 0,913 & 0,361 & 0.000 & 0.005 & Valid \\
\hline & $\times 3.3$ & 0,494 & 0,361 & 0.000 & 0.005 & Valid \\
\hline & $\times 3.4$ & 0,971 & 0,361 & 0.000 & 0.005 & Valid \\
\hline & $\times 3.5$ & 0,971 & 0,361 & 0.000 & 0.005 & Valid \\
\hline \multirow{4}{*}{ Price $(\mathrm{X} 4)$} & $\mathrm{X} 4.1$ & 0,889 & 0,361 & 0.000 & 0.005 & Valid \\
\hline & $\mathrm{X} 4.2$ & 0,878 & 0,361 & 0.000 & 0.005 & Valid \\
\hline & $\mathrm{X} 4.3$ & 0,892 & 0,361 & 0.000 & 0.005 & Valid \\
\hline & $\mathrm{X} 4.4$ & 0,6 & 0,361 & 0.000 & 0.005 & Valid \\
\hline \multirow{6}{*}{ Purchase Satisfaction $(Y)$} & Y1.1 & 0,778 & 0,361 & 0.000 & 0.005 & Valid \\
\hline & Y1.2 & 0,779 & 0,361 & 0.000 & 0.005 & Valid \\
\hline & Y1.3 & 0,799 & 0,361 & 0.000 & 0.005 & Valid \\
\hline & \begin{tabular}{|l}
11.4 \\
\end{tabular} & 0,803 & 0,361 & 0.000 & 0.005 & Valid \\
\hline & Y1.5 & 0,799 & 0,361 & 0.000 & 0.005 & Valid \\
\hline & Y1.6 & 0,803 & 0,361 & 0.000 & 0.005 & Valid \\
\hline
\end{tabular}

The rehabilitation test using SPSS provides facilities for measuring reliability with Cronbach's Alpha statistical test if Cronbach 'alpha test results $>0.6$ then a variable can be said to be good. Reliability test results of question items on questionnaire using 30 respondents are on Table 2.

Table 2 - Reliability Test Results

\begin{tabular}{|l|l|l|l|}
\hline Variable & Alpha Crobach & Criteria & Description \\
\hline Halal Label & 0.985 & 0,6 & Reliabel \\
\hline Brand Image & 0.867 & 0,6 & Reliabel \\
\hline Product Quality & 0.919 & 0,6 & Reliabel \\
\hline Price & 0.835 & 0,6 & Reliabel \\
\hline Purchase Satisfaction & 0.885 & 0,6 & Reliabel \\
\hline
\end{tabular}

Source: Processed data, 2019. 


\section{RESULTS AND DISCUSSION}

Multiple Linear Regression analysis using multiple linear regression calculations with SPSS program version 20.0. It is found in Table 3 as follows:

Table 3

Multiple Regression Analysis Results

\begin{tabular}{|c|c|c|c|c|c|c|}
\hline \multirow{2}{*}{ Model } & \multicolumn{2}{|c|}{ Unstandardized Coefficients } & \multirow{2}{*}{\begin{tabular}{|c} 
Standardized Coefficients \\
Beta \\
\end{tabular}} & \multirow[t]{2}{*}{$\mathbf{t}$} & \multirow[t]{2}{*}{ Sig. } & \multirow[t]{2}{*}{ Description } \\
\hline & $\mathrm{B}$ & Std.Error & & & & \\
\hline (constant) & .578 & .415 & & 1.393 & .166 & \\
\hline Halal Label (X1) & .540 & .069 & .452 & 7.848 & .000 & Sig \\
\hline Brand Image $(\mathrm{X} 2)$ & 2.781 & .209 & 1.972 & 13.281 & .000 & Sig \\
\hline Product Quality (X3) & .969 & .112 & .900 & 8.664 & .000 & Sig \\
\hline Price (X4) & .404 & 110 & .228 & 3.684 & .000 & Sig \\
\hline Dependent Variable & \multicolumn{6}{|c|}{ : Purchase Satisfaction $(\mathrm{Y})$} \\
\hline R Square & \multicolumn{6}{|l|}{0,955} \\
\hline Sign $F$ & \multicolumn{6}{|l|}{$: 0,000$} \\
\hline
\end{tabular}

Processed primer data source, 2019

Based on the results of linear regression analysis in Table 3 obtained the following multiple regression equations:

$$
Y=0.578+2.781 X 1+0.969 \times 2+0.404 \times 3
$$

In the equation above the constant value is obtained by 0.578 which means that if the score on the Halal Label, Brand Image, Product Quality and Price, equals zero (no change) then the purchase decision value is 0.578 .

The regression coefficient of the halal label in the equation is obtained by 0.540 (positive) which means that if awareness about halal labels increases then the purchase messenger keeps increases as well, with a significance value of $0.00<0.05 \%$, meaning hypothesis 1 is proven.

The brand image regression coefficient in the equation is obtained by 2,781 (positive) which means that if the brand image increases then the purchase decision increases as well. With a significance value of $0.00<0.05 \%$, meaning hypothesis 2 is proven.

The price regression coefficient in the equation is obtained by 0.969 (positive) which means that if the quality of the product increases then the purchase decision will also increase. With a significance value of $0.00<0.05 \%$, meaning hypothesis 1 is proven.

The price regression coefficient in the equation is obtained by 0.404 (positive) which means that if the price is affordable or what is paid in accordance with what is obtained by the consumer then the purchase decision will increase. With a significance value of $0.00<$ $0.05 \%$, meaning hypothesis 1 is proven.

\section{DISCUSSION OF RESULTS}

The Effect of Halal Labels on Purchasing Decisions. That there is a significant relationship of halal labels influences purchasing decisions. The inclusion of halal label products is done to provide protection to Muslim consumers, because the many problems of halal labialization in products that contain ingredients that are haram to be consumed to anticipate it, then in the production process the provision of the terms of the terms of a product. The existence of halal labels listed on the product packaging, then directly.

It will have an impact on consumers, especially Muslim communities, to use these products. The emergence of a sense of security and comfort in consuming the product will increase the trust and interest in buying in purchasing decisions. Consumers are increasingly critical to choose a product, thus halal label assurance information is very influential on consumer purchasing decisions. According to Zani's research, Deoranto and Effendi (2013) mentioned that halal labels have a significant influence on purchasing decisions. Therefore, halal labels influence the level of purchasing decisions, the results of this study support previous research. 
The Effect of Brand Image on Purchasing Decisions. Consumers who have a positive image of a brand, will be more likely to make purchases. A better brand is also the basis for building a positive corporate image. According to Kotler and Keller (2012: 263) define brand image as a set of perceptions and beliefs that customers have about a brand that is reflected through associations that exist in the customer's memory. In order to create a good brand image in the mind of consumers, the company must improve the quality of the product. The better the image of a brand, the higher the consumer's decision to make a purchase.

Based on the discussion above, it can be said that the brand image also feeds one of the determining factors of purchasing decisions. This is evidenced by research from Muhammad Taufik Saputro (2018) mentioning that brand image has a positive and significant influence on purchasing decisions.

Effect of Product Quality on Purchasing Decisions. Product quality is also one of the determining factors of purchasing decisions. Consumers will pay close attention before deciding to buy a product, if the product is of good quality. Because a quality product will cause an attraction for consumers to buy the product. According to Kotler and Armstrong (2012:230) defines that: product quality: "is one of the marketer's major positioning tools." Which means the product cauldron is one of the main positions in a marketing. Good product quality will provide its own added value in the minds of consumers. Consumers will be very satisfied if the product they use is of good quality.

Based on the discussion above, it can be said that the product is also one of the determining factors of purchasing decisions. This is evidenced by research from Muhammad Taufik Saputro (2018) mentioned that the quality of products has a significant effect on purchasing decisions. Therefore, product quality influences the level of purchasing decisions and the results of this study support previous research.

Effect of Price on Purchasing Decisions. Price is a factor in consumer considerations in choosing and making purchasing decisions of a product or service. According to Kotler and Keller (2012: 345) describes price as the value that consumers exchange for the benefit of owning and using a product or service that allows the company to earn a reasonable profit by paying for the customer value it creates. Information about prices is important for consumers to know. The price of a product can reflect the quality of the product in question. In addition, before making a purchase decision, consumers usually compare prices elsewhere first. Consumers tend to choose stores that offer cheaper prices compared to rival prices. According to research by Pramudi Artanto and Hendri Sukotjo (2016) mentioned that price has a significant effect on purchasing decisions. Therefore, price influences the level of purchasing decisions, the results of this study support previous research.

\section{CONCLUSION}

Halal labels affect the decision to buy Pop Mie Cup products in Kasihan Bantul Subdistrict. Brand image influences the decision to buy Pop Mie Cup products in Kasihan Bantul Subdistrict. The quality of the product affects the decision to buy Pop Mie Cup products in Kasihan Bantul Subdistrict. Price influences the decision to buy Pop Mie Cup products in Kasihan Bantul District.

The variables examined are: Halal Label, Brand Image, Product Quality, Price, and overall purchase decision shows good results, but can still be improved such as:

- Halal label, at the time of time should be made clear and the contents of the product are really Halal;

- Brand Image, Pop Mie Cup Product Brand has a good reputation in the community, and this should be improved by really maintaining the quality and taste of this product;

- Product Quality, Pop Mie Cup instant noodle products look hygienic, good taste should be improved so that consumers will increasingly like Pop Mie Cup;

- Prices are always evaluated by seeking input from consumers and associated with purchasing power and level of competition so that consumers really feel what they pay according to what they receive. 


\section{REFERENCES}

1. Alma, Buchari. 2013. Manajemen Pemasaran dan Pemasaran Jasa. Bandung: Alfabeta.

2. Arikunto, Suharsimi. 2006. Prosedur Penelitian: Suatu Pendekatan Praktik. Jilid 15. Jakarta: Rineka Cipta.

3. Assauri, Sofjan. 2015. Manajemen Pemasaran: Dasar, Konsep, dan Strategi. Jakarta: PT. Raja Grafindo Persada.

4. Basu Swasta dan Hani Handoko. 2010. Manajemen Pemasaran: Analisa dan Perilaku Konsumen. Yogyakarta: BPFE.

5. Burhanudin. 2011. Perilaku Organisasional. Yogyakarta: CAPS.

6. Daryanto. 2013. Sari Kuliah Manajemen. Jilid 2. Bandung: PT. Sarana Tutorial Nurani Sejahtera.

7. Gaspersz, Vincent. 2011. Total Quality Management ( untuk Praktisi Bisnis dan Industri. Jakarta: Penebar Swadaya

8. Ghozali, Imam. 2013. Aplikasi Multivariate dengan Program IBM SPSS. Yogyakarta: Badan Penerbit Universitas Diponegoro.

9. Hansen, Don R dan Maryanne, M Mowen. 2011. Managerial Accounting (Akuntasi manajerial). Edisi 8. Jilid 2. Jakarta: Salemba Empat.

10. Hansen, Don R dan Maryanne, M Mowen. 2012. Manajemen Biaya. Edisi 8. Jakarta: Salemba Empat.

11. Kotler, Philip dan Gary Armstrong. 2012. Prinsip-prisip Pemasaran. Edisi 13. Diterjemahkan oleh Bob Sabran, MM. Jakarta: Erlangga

12. Kotler, Philip, dan Kevin Lane Keller. 2012. Manajemen Pemasaran. Edisi 13. Jakarta: Erlangga.

13. Kotler, Philip, dan Kevin Lane Keller. 2012. Manajemen Pemasaran. Edisi 13. Diterjemahkan oleh Bob Sabran,MM. Jakarta: Erlangga.

14. Machfoedz, Mahmud. 2010. Komunikasi Pemasaran Modern. Yogyakarta: Cakra llmu.

15. Pedoman dan Tata Cara Pemeriksaan dan Penetapan Pangan Halal Menteri Agama Republik Indonesia No 518 tahun 2001. Dalam: http://www.halalmui.org/images/stories/pdf/dasarhukum/KMA-518-Tahun-2001.pdf., diakses 7 Agustus 2018

16. Peraturan Pemerintah Indonesia Nomor 69 Tahun 1999 Tentang Label dan Iklan.

17. Peter dan Olson. 2013. Perilaku Konsumen dan Strategi Pemasaran. Edisi 9. Diterjemahkan oleh Diah Tantri Dwiandani. Jakarta: Salemba Empat.

18. Rangkuti, Freddy. 2011. Riset Pemasaran. Edisi 10. Jakarta: PT. Gramedia Pustaka Utama.

19. Sandi, A., Marsudi., dan Rahmawanto, D. 2011. "Persepsi Label Halal Terhadap Keputusan Pembelian Konsumen pada Produk Minuman Berenergi". Jurnal Manajemen Bisnis Vol. 1, No, 02, pp 138.

20. Sangadji, E.M., dan Sopiah. 2013. Consumer Behavior: Perilaku Konsumen dan Strategi Pemasaran. Jilid 2. Jakarta: Erlangga.

21. Schiffman, Leon G dan Leslie Lazar Kanuk. 2010. Consumer Behavior. Jakarta: PT. Indeks.

22. Sugiyono. 2013. Statistika Untuk Penelitian. Bandung: Alfabeta.

23. Suharno dan Yudi Sutarso. 2010. Marketing in Pratice. Yogyakarta: Graha IImu.

24. Tjiptono, Fandy dan Anastasia Diana. 2012. Brand Management \& Strategy. Yogyakarta: Andi. 